\title{
Grand Challenges in Urban Agriculture: Ecological and Social Approaches to Transformative Sustainability
}

\begin{abstract}
Karl S. Zimmerer ${ }^{1 *}$, Martha G. Bell ${ }^{2}$, Innocent Chirisa ${ }^{3}$, Chris S. Duvall ${ }^{4}$, Monika Egerer ${ }^{5}$, Po-Yi Hung ${ }^{6}$, Amy M. Lerner ${ }^{7}$, Charlie Shackleton ${ }^{8}$, James David Ward ${ }^{9}$ and Carolina Yacamán Ochoa ${ }^{10}$

${ }^{1}$ GeoSyntheSES Lab, Department of Geography and Programs in Rural Sociology and Ecology, Pennsylvania State University, State College, PA, United States, ${ }^{2}$ Department of Humanities, Pontifical Catholic University of Peru, Lima, Peru, ${ }^{3}$ Faculty of Social and Behavioural Sciences, University of Zimbabwe, Harare, Zimbabwe, ${ }^{4}$ Department of Geography and Environmental Studies, University of New Mexico, Albuquerque, NM, United States, ${ }^{5}$ Department of Life Science Systems, School of Life Sciences, Technical University of Munich, Freising, Germany, ${ }^{6}$ Department of Geography, National Taiwan University, Taipei, Taiwan, ${ }^{7}$ Department of Urban Studies and Planning, University of California, San Diego, San Diego, CA, United States, ${ }^{8}$ Department of Environmental Science, Rhodes University, Grahamstown, South Africa, ${ }^{9}$ Department of Environmental Engineering, University of South Australia, Adelaide, SA, Australia, ${ }^{10}$ Department of Geography, Autonomous University of Madrid, Madrid, Spain
\end{abstract}

Keywords: urban agriculture, sustainable food systems, urban sustainability, sustainability transformations, research challenges, social-ecological integration, peri-urban agriculture

\section{INTRODUCTION}

This synopsis of the Grand Challenges of Urban Agriculture (UA) is framed by the urgent need to understand and strengthen the expanding yet highly diverse roles of UA amid rapid global urbanization, failures of predominant food systems, and crises in systems of physical and mental health. More than half of humanity lives in cities today and by 2030 this is projected to grow to 60.4 percent, $\sim 5$ billion people (UN Habitat, 2020). More than 90 percent of urban demographic increase is anticipated to take place in the developing world.

Ecological and social dimensions of UA are situated in these expanding spaces of cities, towns, and villages (along with their urban fringe or peri-urban areas), and among their diverse populations. UA is further situated in the powerful, far-reaching influences of urbanization processes that occur within and beyond these spaces. UA is thus integral to the prospect of Urban Sustainability as SDG 11 ("Make cities and human settlements inclusive, safe, resilient and sustainable”) of the U.N.'s 2030 Agenda for Sustainable Development.

Predominant agri-food systems are currently failing to provide healthy diets to the world while causing planetary externalities of environmental damage that both create and compound social injustices. As described below, UA has critical roles to play in strengthening food systems and the sustainability and justice of these functions in addition to benefits such as contributing vital new approaches to address crises of physical and mental health. Such contributions occur while recognizing the fuller scope of these societal problems. In response to such concerns, the Grand Challenges of UA serve as a clarion call for the integration of ecological and social research to advance this expansive frontier of sustainable food systems.

Addressing the Grand Challenges requires UA research to integrate across the biological, ecological, health, engineering, energy, and geophysical sciences as well as the disciplines of the social sciences and the fields of planning, design, and policy. UA research is well-suited to and indeed requires expanding applications of inter- and transdisciplinary frameworks such 
as social-ecological systems, social agroecology, sustainable livelihoods, environment-focused political ecology, cultural landscape and food-territory analysis, community studies, social justice and anti-racism movements, and sustainability science. To describe the social and ecological connections of UA through such frameworks, our synopsis of Grand Challenges refers to both the mechanisms of strong ties (linkages) and to the dynamics of more diffuse yet nonetheless powerful influences (entanglements).

Widespread engagement of diverse, non-academic stakeholders in UA reinforces the call to integrate ecological and social analyses through diverse knowledge systems and practices. The centrality of their engagement in UA highlights the urgency of strengthening solutions in projects, programs, and policies, thus further propelling the need for integrated ecological and social research.

Our article is intended to identify, highlight, and synopsize the Grand Challenges of ecological and social analyses in UA research, including future literature reviews and structured analyses. Thus, we call for research to address two principal themes of UA Grand Challenges: (i) UA ecological and social multi-functionality; and (ii) relationships of UA governance to social and ecological systems. We conclude with a call for research to leverage these Grand Challenges to strengthen sustainability and resilience through transformative UA.

\section{UNDERSTAND AND SUPPORT CONNECTED UA ECOLOGICAL AND SOCIAL MULTI-FUNCTIONALITY}

Several challenges of UA research are focused on determining the linkages and entanglements of ecological and social multifunctionality (Zasada, 2011). One principal focus has been the estimation of UA food yields, consumption levels, and efficiency (McDougall et al., 2019; Csortan et al., 2020). These estimations have occurred in UA case studies across a variety of geographic spaces and time frames (e.g., Crush et al., 2011; Karg et al., 2020). Though UA is unlikely to replace large-scale food systems, the potential benefits - and limitations - of UA's specific functions in a better food system remain elusive and constitute a vital challenge for UA research.

The range of research challenges associated with UA multi-functionality extends to both the direct social-ecological linkages of food, nutrition, and health as well as the crucial ecosystem services (Clinton et al., 2018), such as soilwater, pollinator, biodiversity, ecological restoration. and more diffuse yet influential entanglements with these factors and others. Prior to brief synopsis of each, we foreshadow the similar importance, which is examined in the next section, of UA's extensive governance-influenced ecological and social linkages and entanglements involving institutions, communities, and individuals.

Challenges of UA research on linked ecological and social multi-functionality are rooted in the diverse humanenvironment spaces of gardening, farming, foraging, livestock and food-animal tending, and other activities. UA research challenges traverse multiple social levels (e.g., individual, household, community) and spatial scales and settings (e.g., cities, towns and villages, core urban, urban fringe or periurban, individual plot, landscape). This rich diversity of spaceand place-based practices provides for the production and procurement of plants, animals, and biota of wide-ranging food, medicinal, and sociocultural goods as well as a panoply of potential related benefits such as outdoor enjoyment, social empowerment, food-environment experiences (see details below and Shackleton et al., 2017). The challenge of understanding these practices as integral parts of UA ecological and social multi-functionality is driven also by the expanding spectrum of urbanization impacts related to wide-ranging variations of the size, location, demographics, development, socioeconomic, and cultural characteristics of human settlements.

Active transformation of UA spaces extends from the shifting demographics of diverse neighborhoods located in and beyond city cores (Brown and Jameton, 2000) to UA in urban-fringe areas and urban-rural interfaces whose blurred boundaries reflect increased spatial inter-connectedness (Lerner and Eakin, 2011; Zimmerer et al., 2020a). Global urban expansion and differentiation are thus both strengthening and compounding the diverse processes and patterns affecting UA that present a new wave of research challenges. One example of recent urban expansion and differentiation propelling new research challenges is the estimated global-scale continuity of agricultural areas in urban fringe spaces (Thebo et al., 2014), a trend that co-exists with urbanization-driven farmland loss. Another important dimension is reflected in the emerging new global geographies of rapid urbanization. With $\sim 95 \%$ of urban growth in the next 30 years forecast to occur in developing countries, many research challenges will concentrate in these regions (UN Habitat, 2020).

Understanding the social-ecological linkages of key urbanization processes-ranging from supply chains and demographics to technology development-contribute to new challenges in UA research amid these massive shifts (Saha and Eckelman, 2017; Carolan, 2020). These challenges extend in the reciprocal direction whereby it is vital to determine the influence of UA characteristics, as they unfold, on subsequent landscape, biodiversity, and resilience capacities of cities (McPhearson et al., 2014; Kremer et al., 2016a,b). Moreover, these changes challenge research to understand better how UA is being influenced through accelerated innovation, development, and implementation of new agricultural technologies such as indoor horticulture and vertical gardens amid numerous others (Thomaier et al., 2015; Hallett et al., 2016; Carolan, 2020).

Temporal dynamism, evidenced by historical UA case studies in the U.S. (Bassett, 1981), Europe, and wide-ranging international contexts (e.g., Lima, Peru, during the Spanish colonial period; Bell, 2018), reveal the short- and long-term social-ecological trajectories of UA in complex societies. These diverse trajectories include peri-urban areas and food chains, as well as attention to gardening per se (Doolittle, 2004), that evidence the fuller spatiotemporal scope of UA functions. These insights signal a challenge for new research to understand the range of UA temporal and spatial dynamics in relation to governance (see next section). 
UA potentially offers additional key linkages to sustainable food systems through its benefits to physical and psychological health (Pollard et al., 2018). Estimated contributions of UAderived food to diet and nutrition, including factors such as protein intake, suggest its role is limited in overall scope but not trivial (Ward J. D. et al., 2014). Moreover, UA spaces such as gardens can play roles that are secondary in overall food supply but nonetheless crucial (and statistically significant) in regard to human nutrition (Jones et al., 2018). Expanding interest centers on UA-provisioned foods that deliver nutrition and health benefits due to quality and diversity, enhanced access, fit with sociocultural foodways, and potential contributions to food and nutrition security (e.g., Shackleton et al., 2009). These linkages are shown to include the benefits of outdoor exercise, personal satisfaction, and connection with nature (McLain et al., 2014).

Understanding and strengthening UA multi-functionality amid the global COVID-19 pandemic pose diverse research challenges. These include emphasis on UA capacities to address pandemic-worsened food and nutrition insecurity (e.g., Lal, 2020). Among those suffering the pandemic's most pronounced adverse effects on food and nutrition insecurity are large urban populations among the estimated 1.6 billion workers whose wages have been reduced and the estimated 71 million people being pushed back into extreme poverty (UN Habitat, 2020).

At the same time, the challenges for UA research studying and strengthening multi-functionality extend well-beyond food and nutrition per se amid the global COVID-19 pandemic and potential post-pandemic phases. One priority is the analysis of potential shifts in UA ecological and social functions related to the COVID-19 pandemic. A particular area of research challenges is to examine social-ecological interactions of UA in time frames focused on both the COVID-19 pandemic as well as before and after. These interactions range from issues of sociocultural values and access, on the one hand, to ones of broad changes associated with potentially transformative UA (see final section below). They will need to focus, for example, on the impact of the COVID-19 pandemic on the potential expansion and possible transformation of UA functions, benefits, sustainability, governance, and justice dimensions and, similarly vital, how to strengthen these (Pulighe and Lupia, 2020).

Notwithstanding surging interest, specific UA linkages to generalizable health outcomes, both physical and psychological, are not well-understood and robust new analysis of this multifunctionality is needed (Siegner et al., 2018; Audate et al., 2019). Similarly, investigation is needed of proposed "multiplier effects" of entangled food, health, and nutrition benefits stemming from the kinds of knowledge and awareness that are gained in UA experience (Surls et al., 2015).

Substantial advances are taking place in the challenge to link site-based agroecological processes and pattern to broader contexts (Egerer and Cohen, 2020). The soil properties of community gardens, for instance, can be linked to neighborhood socio-demographic characteristics (Egerer et al., 2018). Other examples illustrate how UA typically hinges on multi-scale spatial flows of water, nutrient, and biotic resources (such as pollinators), as well as broadly defined social factors, knowledge, management, and policy (Ward J. et al., 2014; Lin et al., 2015; Langellotto et al., 2018; Graefe et al., 2019). These landscape flows are being found to correspond to spaces or scales both within and across urban areas as well-traversing periurban and urban-rural interfaces (Soulard et al., 2018). Such findings furnish crucial inputs to UA design and planning, including elements of basic information on where and how UA can effectively support these agroecological functions.

A similar emergent challenge concerns research on climate change impacts and potential adaptations arising through UA ecological, social, and spatial processes (Egerer, 2020). Analysis of these interactions coalesce around specific topics such as UA relations to urban heat islands (Pearson et al., 2010) as well as runoff and flood-risk reduction, windstorm control benefits, and benefits to climate change mitigation such as carbon storage and sequestration and the reduction of energy use and emissions (Lwasa and Dubbeling, 2016; Egerer, 2020).

Related UA research challenges are centered on the complex ecological, social, and spatial factors that condition UA biodiversity. UA patches in cities and in city-fringe areas are being found to support agrobiodiverse plant and animal foods that represent domesticates, semi-domesticates, and wild foods as well as many underutilized species and integral agroecosystem components (e.g., soil biota, pollinators, beneficial insects; Lerner et al., 2013; Zimmerer and Carney, 2019; Zimmerer et al., 2019) yet further systematic research is needed (Clucas et al., 2018). Distinct though related is the food agrobiodiversity of retail shops. Ranging from convenience stores to supermarkets, they intermix with UA spaces, thereby jointly influencing urban food environments (Duvall et al., 2010; Minaker et al., 2016).

\section{DETERMINE GOVERNANCE RELATIONS TO UA SOCIAL AND ECOLOGICAL SYSTEMS}

UA governance issues stem from organizational practices involving the wide-ranging realms of economics and policy as well as a diverse suite of community building, activist, and sociocultural practices. One challenge for UA research is to understand the social and ecological linkages of both short food chains connecting proximate production and consumption (Moustier and Renting, 2015; Yacamán Ochoa et al., 2020b) as well as long-distance economic specialization or even bulk commodity production that can connect UA farming to faraway producers and consumers (Hung, 2016; Opitz et al., 2016). Consumption practices, including such basic functions as cooking and access to food-preparing spaces, are integrally related to UA.

A similar research challenge corresponds to UA labor sourcing. It can entangle local networks of individuals, households, and communities, including many whose nonfarm income helps to support or even subsidize certain UA styles (Lerner and Eakin, 2011). By contrast, other UA systems incorporate farm worker and immigrant populations (Zimmerer et al., 2020a). Other approaches to UA activities are experience-based and center on the roles of race and antiracism (Reese, 2018). These can further incorporate demographic 
variation ranging from young people and the elderly in urban neighborhoods to the UA spaces of incarcerated persons.

Insights on the entanglements of UA governance reinforce the challenge of orienting integrated UA social and ecological research "beyond methodological city-ism" (Connolly, 2019). "Beyond city-ism" means framing UA research both within urban sites and extending the scale of analysis to the city fringe and, in some cases, to the connections with surrounding rural spaces and beyond. This challenge requires UA perspectives that can address the roles of infrastructural, planning, and design systems including transport, water, food, and green infrastructure as well as built-environment research (Pollalis, 2016; Lin et al., 2017; Pinna, 2017; Yacamán Ochoa et al., 2020a; Zimmerer et al., 2021).

A second challenge consists of calls to analyze UA in the multiple, inter-sectoral dimensions of FEWs (Food, Energy, and Water) and related resource-interaction frameworks. One approach well-suited to UA has positioned the role of people ("P") at the center of FEW analysis (FEWP; Caputo et al., 2020). This approach and others can be incorporated into UA research challenges in specific regional or national-level FEW frameworks (e.g., sub-Saharan Africa; Chirisa and Bandauko, 2015).

Policy issues represent many of the most visible, compelling research challenges on UA governance. Though previously minor, food is being transformed into a centerpiece of urban policy issues where research challenges extend well-beyond safety and narrow regulatory concerns (Pothukuchi and Kaufman, 1999; Morgan, 2009). Urban food planning and analysis are shedding new light on specific regulations of production, distribution, consumption, and social initiatives (Dawson and Morales, 2016), cultural practices (Hammelman and HayesConroy, 2015), and case studies of specific cities (e.g., New York and Toronto; Cohen and Reynolds, 2014; Mulligan et al., 2018). Significant UA research challenges are centered on the need to create policies that can respond to the spatial, temporal, and human-environment complexities of UA social and ecological functions (see preceding section).

UA research challenges extend to analysis of overarching drivers such as neoliberal structural adjustment and globalization policies that propel the powerful food and urbanization trends setting the current stage for UA worldwide (Bosco and JoassartMarcelli, 2017). These challenges encompass UA analysis needed to focus on influences of government agencies and non-state actors (e.g., NGOs; Olivier and Heinecken, 2017), individual program, projects, and solution-specific analysis (Pollard et al., 2017b; McClintock and Simpson, 2018), and effects related to broader networked urban green infrastructure (Rolf et al., 2020).

Research challenges related to expanding UA activism examine how specific governance issues entangle with ecological and social processes through social organizations, cultural practices, and spatial strategies. For instance, community-based governance initiatives such as food hubs can exert influence on UA production systems (Levkoe et al., 2018; Hammelman et al., 2020). Cultural imaginaries of urban political agroecologies might serve as a source of transformative rethinking and action. This challenge is designed as "non-celebratory," meaning it subverts the triumphalism of naïve UA interpretation, by linking analysis to political economies and multi-layered realities of social power in cities involving racism, gendering, commodification, and other forces. Moreover, UA experience exerts an influence on the human relationship to symbolic meanings and ecological effects of urban nature, pushing research to think beyond the human-centered perspective. These UA research challenges are well-suited to further advancements via the conceptual orientations of political ecology, feminist political ecology, multi-species entanglements, and critical, more-thanhuman geography (Hovorka, 2006; Tornaghi, 2014; Classens, 2015; Nyantakyi-Frimpong et al., 2016).

This emphasis on bottom-up styles of UA governance reveals the power of a justice perspective for changing ecological and social issues (Gray et al., 2014; Reynolds and Cohen, 2016; Reynolds et al., 2020). It highlights the influence on UA of social justice movements allied with alternative food networks, "rights to the city" (Cabannes and Raposo, 2013; Shillington, 2013; Purcell and Tyman, 2015), food citizenship (Baker, 2004; Travaline and Hunold, 2010), food sovereignty (Block et al., 2012), food territories and landscapes, and citizen science (Pollard et al., 2017a).

The role of UA in citizen rights and practices, for example, can strengthen senses of belonging and place among diverse populations that include the housing insecure. These movements add crucial context to understanding UA's valuation of nature, as being documented in scientific and economic approaches (Keeler et al., 2019), while revealing the roles of the gentrification (induced through property valuation that can arise as a UA consequence; McClintock, 2018) and "sustainability fixes" (Pirro and Anguelovski, 2017).

Additional challenges in UA governance research are focused on systematic comparisons of multiple parameters, including social-ecological interactions, across case studies. UA case studies can be aggregated at such levels as cities, countries, and world regions (De Bon et al., 2010; Taylor and Lovell, 2014; Lohrberg et al., 2016; DuŽí et al., 2017; Gray et al., 2017; Soulard et al., 2017a; WinklerPrins, 2017; Diehl et al., 2020). Comparing and contrasting developing and developed countries, or the Global North and Global South, shows the convergence of certain UA trends along with continued distinctness (Bryld, 2003; WinklerPrins, 2017; Gray et al., 2020). Focus on the dynamics of social-ecological systems is emerging as an important challenge of comparative, site-based UA research (Lohrberg et al., 2016).

\section{CONCLUSION: BROADENING THE UA FOCUS ON SUSTAINABILITY AND RESILIENCE, AND TRANSFORMATION}

We conclude by arguing that integrated social and ecological analysis of UA can contribute solutions that expand the sustainability and resilience of food systems and cities (see also de Zeeuw and Drechsel, 2015; Soulard et al., 2017b; Egerer and Cohen, 2020). Our synopsis is centered on highlighting the Grand Challenges in UA research as well as other focal points of rapid social-ecological change that are spurring increased attention to transformation as a key research concept. Transformation refers to major, often abrupt social-ecological changes as analyzed in current or historical UA and is particularly well-suited to understanding the extensive scope of UA Grand 
Challenges (Tornaghi and Dehaene, 2019; Zimmerer et al., 2020a).

The concept of transformation frequently encompasses a prescriptive dimension that aims to bridge ecological sustainability with the justice concerns of communities and social movements (Warner et al., 2020; Zimmerer et al., 2020b), thus promises to align still further with new UA research challenges. Indeed, interest in UA among stakeholders, researchers, and others can be and is often fueled by its potential to generate social-ecological processes that strengthen community and social empowerment.

These UA social-ecological processes can propel the transformative sharing of resources, spaces, knowledge, and participation in community organizations and social movements. Such UA social-ecological interactions potentially incorporate and extend beyond concerns for sustainable ecosystems, production, and social empowerment per se. Here UA has the potential to generate the embodied experiences of collective values, worldviews, and cosmovisions that are similarly key to transformative sustainability (O’Brien and Sygna, 2013).

\section{REFERENCES}

Audate, P. P., Fernandez, M. A., Cloutier, G., and Lebel, A. (2019). Scoping review of the impacts of urban agriculture on the determinants of health. BMC Public Health 19, 1-14. doi: 10.1186/s12889-019-6885-z

Baker, L. E. (2004). Tending cultural landscapes and food citizenship in Toronto's community gardens. Geogr. Rev. 94, 305-325. doi: 10.1111/j.1931-0846.2004.tb00175.x

Bassett, T. J. (1981). Reaping on the margins: a century of community gardening in America. Landscape 25, 1-8.

Bell, M. G. (2018). "Wheat is the nerve of the whole republic": spatial histories of a European crop in colonial Lima, Peru, 1535-1705. J. Hist. Geogr. 59, 40-51. doi: 10.1016/j.jhg.2017.10.002

Block, D. R., Chávez, N., Allen, E., and Ramirez, D. (2012). Food sovereignty, urban food access, and food activism: contemplating the connections through examples from Chicago. Agric. Hum. Values 29, 203-215. doi: 10.1007/s10460-011-9336-8

Bosco, F. J., and Joassart-Marcelli, P. (2017). "Gardens in the city: community, politics, and place in San Diego, California," in Global Urban Agriculture, ed A. WinklerPrins (Boca Raton, FL: CABI), p. 50-65. doi: 10.1079/9781780647326.0050

Brown, K. H., and Jameton, A. L. (2000). Public health implications of urban agriculture. J. Public Health Policy 21, 20-39. doi: 10.2307/3343472

Bryld, E. (2003). Potentials, problems, and policy implications for urban agriculture in developing countries. Agric. Hum. Values 20, 79-86. doi: 10.1023/A:1022464607153

Cabannes, Y., and Raposo, I. (2013). Peri-urban agriculture, social inclusion of migrant population and right to the city: practices in Lisbon and London. City 17, 235-250. doi: 10.1080/13604813.2013. 765652

Caputo, S., Schoen, V., Specht, K., Grard, B., Blythe, C., Cohen, N., et al. (2020). Applying the food-energy-water nexus approach to urban agriculture: from FEW to FEWP (Food-Energy-Water-People). Urban Forestry Urban Green. 58:126934. doi: 10.1016/j.ufug.2020.126934

Carolan, M. (2020). “Urban farming is going high tech": digital urban agriculture's links to gentrification and land use. J. Am. Plan. Assoc. 86, 47-59. doi: $10.1080 / 01944363.2019 .1660205$

Chirisa, I., and Bandauko, E. (2015). African cities and the water-foodclimate-energy nexus: an agenda for sustainability and resilience at a local level. Urban Forum 26, 391-404. doi: 10.1007/s12132-015-9 256-6

\section{AUTHOR CONTRIBUTIONS}

KSZ was lead author. All other authors provided intellectual and edit inputs.

\section{FUNDING}

Funding for this research was provided through the award to KSZ of the Ruby S. and E. Willard Miller Professorship at the Department of Geography, Pennsylvania State University.

\section{ACKNOWLEDGMENTS}

KSZ acknowledges intellectual interactions with several colleagues in the general background and specific preparation of this article. These include Christophe Soulard, Antoinette WinklerPrins, Rafael Mata Olmo, Leslie Gray, Tom Bassett, Julie Guthman, Stef de Haan, Yolanda Jiménez de Olivencia, Tobias Plieninger, Lauren Baker, Connie Almekinders, Carolyn Sachs, Judith Carney, Ryan Galt, and Jennifer Blesh.

Classens, M. (2015). The nature of urban gardens: toward a political ecology of urban agriculture. Agric. Hum. Values 32, 229-239. doi: 10.1007/s10460-014-9540-4

Clinton, N., Stuhlmacher, M., Miles, A., Uludere Aragon, N., Wagner, M., Georgescu, M., et al. (2018). A global geospatial ecosystem services estimate of urban agriculture. Earth Future 6, 40-60. doi: 10.1002/2017EF000536

Clucas, B., Parker, I. D., and Feldpausch-Parker, A. M. (2018). A systematic review of the relationship between urban agriculture and biodiversity. Urban Ecosyst. 21, 635-643. doi: 10.1007/s11252-018-0748-8

Cohen, N., and Reynolds, K. (2014). Urban agriculture policy making in New York's "New political spaces": strategizing for a participatory and representative system. J. Plan. Educ. Res. 34, 221-234. doi: 10.1177/0739456X14526453

Connolly, C. (2019). Urban political ecology beyond methodological cityism. Int. J. Urban Region. Res. 43, 63-75. doi: 10.1111/1468-2427.12710

Crush, J., Hovorka, A., and Tevera, D. (2011). Food security in Southern African cities: the place of urban agriculture. Prog. Dev. Stud. 11, 285-305. doi: 10.1177/146499341001100402

Csortan, G., Ward, J., and Roetman, P. (2020). Productivity, resource efficiency and financial savings: an investigation of the current capabilities and potential of South Australian home food gardens. PLOS ONE 15:e0230232. doi: 10.1371/journal.pone.0230232

Dawson, J. C., and Morales, A. (Eds.). (2016). Cities of Farmers: Urban Agricultural Practices and Processes. Iowa City: University of Iowa Press. doi: $10.2307 /$ j.ctt20q23dv

De Bon, H., Parrot, L., and Moustier, P. (2010). Sustainable urban agriculture in developing countries: a review. Agron. Sustain. Dev. 30, 21-32. doi: 10.1051/agro:2008062

de Zeeuw, H., and Drechsel, P. (Eds.). (2015). Cities and Agriculture: Developing Resilient Urban Food Systems. London: Routledge. doi: 10.4324/9781315716312

Diehl, J. A., Sweeney, E., Wong, B., Sia, C. S., Yao, H., and Prabhudesai, M. (2020). Feeding cities: Singapore's approach to land use planning for urban agriculture. Glob. Food Secur. 26:100377. doi: 10.1016/j.gfs.2020.100377

Doolittle, W. E. (2004). Gardens are us, we are nature: transcending antiquity and modernity. Geogr. Rev. 94, 391-404. doi: 10.1111/j.1931-0846.2004.tb00179.x

Duvall, C. S., Howard, P. H., and Goldsberry, K. (2010). Apples and oranges? Classifying food retailers in a midwestern US city based on the availability of fresh produce. J. Hung. Environ. Nutr. 5, 526-541. doi: $10.1080 / 19320248.2010 .527281$

DuŽí, B., Frantál, B., and Rojo, M. S. (2017). The geography of urban agriculture: new trends and challenges. Moravian Geogr. Rep. 25, 130-138. doi: 10.1515/mgr-2017-0012 
Egerer, M. (2020). "Climate factors and climate change in urban agroecosystems," in Urban Agroecology: Interdisciplinary Research and Future Directions, eds M. Egerer, and H. Cohen (Boca Raton, FL: CRC Press), 79-94. doi: 10.1201/9780429290992-3

Egerer, M., and Cohen, H. (Eds.). (2020). Urban Agroecology: Interdisciplinary Research and Future Directions. Boca Raton, FL: CRC Press. doi: 10.1201/9780429290992

Egerer, M. H., Philpott, S. M., Liere, H., Jha, S., Bichier, P., and Lin, B. B. (2018). People or place? Neighborhood opportunity influences community garden soil properties and soil-based ecosystem services. Int. J. Biodivers. Sci. Ecosyst. Serv. Manag. 14, 32-44. doi: 10.1080/21513732.2017.14 12355

Graefe, S., Buerkert, A., and Schlecht, E. (2019). Trends and gaps in scholarly literature on urban and peri-urban agriculture. Nutr. Cycl. Agroecosyst. 115, 143-158. doi: 10.1007/s10705-019-10018-z

Gray, L., Diekmann, L., and Algert, S. (2017). "North American urban agriculture: barriers and benefits," in Global Urban Agriculture, ed A. M. G. A. WinklerPrins (Wallingford: CABI Publishing), p. 24-37. doi: 10.1079/97817806473 26.0024

Gray, L., Elgert, L., and WinklerPrins, A. (2020). Theorizing urban agriculture: north-south convergence. Agric. Hum. Values 37, 869-883. doi: 10.1007/s10460-020-10015-x

Gray, L., Guzman, P., Glowa, K. M., and Drevno, A. G. (2014). Can home gardens scale up into movements for social change? The role of home gardens in providing food security and community change in San Jose, California. Local Environ. 19, 187-203. doi: 10.1080/13549839.2013.792048

Hallett, S., Hoagland, L., Toner, E., Gradziel, T. M., Mitchell, C. A., and Whipkey, A. L. (2016). Urban agriculture: environmental, economic, and social perspectives. Hortic. Rev. 44, 65-120. doi: 10.1002/9781119281269.ch2

Hammelman, C., and Hayes-Conroy, A. (2015). Understanding cultural acceptability for urban food policy. J. Plan. Lit. 30, 37-48. doi: 10.1177/0885412214555433

Hammelman, C., Levkoe, C., Agyeman, J., Kharod, S., Faus, A. M., Munoz, E., et al. (2020). Integrated food systems governance. J. Agric. Food Syst. Commun. Dev. 9, 71-86. doi: 10.5304/jafscd.2020.092.003

Hovorka, A. J. (2006). The No. 1 Ladies' Poultry Farm: a feminist political ecology of urban agriculture in Botswana. Gender Place Cult. 13, 207-225. doi: 10.1080/09663690600700956

Hung, P. Y. (2016). Tea Production, Land Use Politics, and Ethnic Minorities: Struggling over Dilemmas in China's Southwest Frontier. New York, NY: Springer. doi: 10.1057/9781137494085

Jones, A. D., Creed-Kanashiro, H., Zimmerer, K. S., de Haan, S., Carrasco, M., Mesa, K., et al. (2018). Farm-level agricultural biodiversity in Peru is associated with greater odds of women achieving a minimally diverse and micronutrient adequate diet. J. Nutr. 148, 1625-1637. doi: 10.1093/jn/nxy166

Karg, H., Drechsel, P., Dittrich, N., and Cauchois, A. (2020). Spatial and temporal dynamics of croplands in expanding West African cities. Urban Agric. Region. Food Syst. 5:20005. doi: 10.1002/uar2.20005

Keeler, B. L., Hamel, P., McPhearson, T., Hamann, M. H., Donahue, M. L., and Prado, K. A. M. (2019). Social-ecological and technological factors moderate the value of urban nature. Nat. Sustain. 2, 29-38. doi: 10.1038/s41893-018-0202-1

Kremer, P., Hamstead, Z., Haase, D., McPhearson, T., Frantzeskaki, N., Andersson, E., et al. (2016a). Key insights for the future of urban ecosystem services research. Ecol. Society 21:2. doi: 10.5751/ES-08445-210229

Kremer, P., Hamstead, Z. A., and McPhearson, T. (2016b). The value of urban ecosystem services in New York City: a spatially explicit multicriteria analysis of landscape scale valuation scenarios. Environ. Sci. Policy 62, 57-68. doi: 10.1016/j.envsci.2016.04.012

Lal, R. (2020). Home gardening and urban agriculture for advancing food and nutritional security in response to the COVID-19 pandemic. Food Secur. 12, 871-876. doi: 10.1007/s12571-020-01058-3

Langellotto, G. A., Melathopoulos, A., Messer, I., Anderson, A., McClintock, N., and Costner, L. (2018). Garden pollinators and the potential for ecosystem service flow to urban and peri-urban agriculture. Sustainability 10:2047. doi: $10.3390 /$ su10062047
Lerner, A. M., and Eakin, H. (2011). An obsolete dichotomy? Rethinking the ruralurban interface in terms of food security and production in the global south. Geogr. J.177, 311-320. doi: 10.1111/j.1475-4959.2010.00394.x

Lerner, A. M., Eakin, H., and Sweeney, S. (2013). Understanding periurban maize production through an examination of household livelihoods in the Toluca Metropolitan Area, Mexico. J. Rural Stud. 30, 52-63. doi: 10.1016/j.jrurstud.2012.11.001

Levkoe, C. Z., Hammelman, C., Craven, L., Dandy, G., Farbman, J., Harrison, J., et al. (2018). Building sustainable communities through food hubs. J. Agric. Food Syst. Comm. Dev. 8, 107-122. doi: 10.5304/jafscd.2018.082.008

Lin, B. B., Philpott, S. M., and Jha, S. (2015). The future of urban agriculture and biodiversity-ecosystem services: challenges and next steps. Basic Appl. Ecol. 16, 189-201. doi: 10.1016/j.baae.2015.01.005

Lin, B. B., Philpott, S. M., Jha, S., and Liere, H. (2017). "Urban agriculture as a productive green infrastructure for environmental and social well-being," in Greening Cities, eds P. Y. Tan, and C. Y. Jim (Singapore: Springer), p. 155-179. doi: 10.1007/978-981-10-4113-6_8

Lohrberg, F., Lička, L., Scazzosi, L., and Timpe, A. (Eds.). (2016). Urban Agriculture Europe. Berlin: Jovis.

Lwasa, S., and Dubbeling, M. (2016). "Urban agriculture and climate change," in Cities and Agriculture: Developing Resilient Urban Food Systems, eds H. de Zeeuw, and P. Drechsel (London: Routledge), p. 192-217.

McClintock, N. (2018). Cultivating (a) sustainability capital: urban agriculture, ecogentrification, and the uneven valorization of social reproduction. Ann. Am. Assoc. Geogr. 108, 579-590. doi: 10.1080/24694452.2017.13 65582

McClintock, N., and Simpson, M. (2018). Stacking functions: identifying motivational frames guiding urban agriculture organizations and businesses in the United States and Canada. Agric. Hum. Values 35, 19-39. doi: 10.1007/s10460-017-9784-x

McDougall, R., Kristiansen, P., and Rader, R. (2019). Small-scale urban agriculture results in high yields but requires judicious management of inputs to achieve sustainability. Proc. Natl. Acad. Sci. U.S.A. 116, 129-134. doi: 10.1073/pnas.1809707115

McLain, R., Hurley, P., Emery, M., and Poe, M. (2014). Gathering "wild" food in the city: rethinking the role of foraging in urban ecosystem planning and management. Local Environ. 19, 220-240. doi: 10.1080/13549839.2013.8 41659

McPhearson, T., Hamstead, Z. A., and Kremer, P. (2014). Urban ecosystem services for resilience planning and management in New York City. Ambio 43, 502-515. doi: 10.1007/s13280-014-0509-8

Minaker, L. M., Shuh, A., Olstad, D. L., Engler-Stringer, R., Black, J. L., and Mah, C. L. (2016). Retail food environments research in Canada: a scoping review. Can. J. Public Health 107, eS4-eS13. doi: 10.17269/cjph.107.5724

Morgan, K. (2009). Feeding the city: the challenge of urban food planning. Int. Plan. Stud. 14, 341-348. doi: 10.1080/13563471003642852

Moustier, P., and Renting, H. (2015). "Urban agriculture and short chain food marketing in developing countries," in Cities and Agriculture. Developing Resilient Urban Food Systems, eds H. De Zeeuw, and P. Drechsel (London: Routledge) p.121-138.

Mulligan, K., Archbold, J., Baker, L. E., Elton, S., and Cole, D. C. (2018). Toronto municipal staff and policy-makers' views on urban agriculture and health. $J$. Agric. Food Syst. Commun. Dev. 8, 133-156. doi: 10.5304/jafscd.2018.08B.001

Nyantakyi-Frimpong, H., Arku, G., and Inkoom, D. K. B. (2016). Urban agriculture and political ecology of health in municipal Ashaiman, Ghana. Geoforum 72, 38-48. doi: 10.1016/j.geoforum.2016.04.001

O’Brien, K., and Sygna, L. (2013). "Responding to climate change: the three spheres of transformation," in Proceedings of Transformation in a Changing Climate, 19-21, June 2013 (Oslo: University of Oslo) p.16-23.

Olivier, D. W., and Heinecken, L. (2017). The personal and social benefits of urban agriculture experienced by cultivators on the Cape flats. Dev. South. Afr. 34, 168-181. doi: 10.1080/0376835X.2016.1259988

Opitz, I., Berges, R., Piorr, A., and Krikser, T. (2016). Contributing to food security in urban areas: differences between urban agriculture and periurban agriculture in the Global North. Agric. Hum. Values 33, 341-358. doi: 10.1007/s10460-015-9610-2 
Pearson, L. J., Pearson, L., and Pearson, C. J. (2010). Sustainable urban agriculture: stocktake and opportunities. Int. J. Agric. Sustain. 8, 7-19. doi: 10.3763 /ijas.2009.0468

Pinna, S. (2017). Sowing landscapes: social and ecological aspects of food production in peri-urban spatial planning initiatives-a study from the Madrid area. Fut. Food J. Food Agric. Soc. 5, 34-45.

Pirro, C., and Anguelovski, I. (2017). Farming the urban fringes of Barcelona: competing visions of nature and the contestation of a partial sustainability fix. Geoforum 82, 53-65. doi: 10.1016/j.geoforum.2017.03.023

Pollalis, S. N. (2016). Planning Sustainable Cities: An Infrastructure-Based Approach. Oxford: Routledge. doi: 10.4324/9781315642352

Pollard, G., Roetman, P., and Ward, J. (2017a). The case for citizen science in urban agriculture research. Future Food J. Food Agric. Soc. 5, 9-20.

Pollard, G., Roetman, P., Ward, J., Chiera, B., and Mantzioris, E. (2018). Beyond productivity: considering the health, social value and happiness of home and community food gardens. Urban Sci. 2:97. doi: 10.3390/urbansci2040097

Pollard, G., Ward, J. D., and Koth, B. (2017b). Aquaponics in urban agriculture: social acceptance and urban food planning. Horticulturae 3:39. doi: 10.3390/horticulturae3020039

Pothukuchi, K., and Kaufman, J. L. (1999). Placing the food system on the urban agenda: the role of municipal institutions in food systems planning. Agric. Hum. Values 16, 213-224. doi: 10.1023/A:1007558805953

Pulighe, G., and Lupia, F. (2020). Food first: COVID-19 outbreak and cities lockdown a booster for a wider vision on urban agriculture. Sustainability 12:5012. doi: 10.3390/su12125012

Purcell, M., and Tyman, S. K. (2015). Cultivating food as a right to the city. Local Environ. 20, 1132-1147. doi: 10.1080/13549839.2014.903236

Reese, A. M. (2018). "We will not perish; we're going to keep flourishing": race, food access, and geographies of self-reliance. Antipode 50, 407-424. doi: 10.1111 /anti.12359

Reynolds, K., Block, D. R., Hammelman, C., Jones, B. D., Gilbert, J. L., and Herrera, H. (2020). Envisioning radical food geographies: shared learning and praxis through the food justice scholar-activist/activist-scholar community of practice. Hum. Geogr. 13, 277-292. doi: 10.1177/1942778620951934

Reynolds, K., and Cohen, N. (2016). Beyond the Kale: Urban Agriculture and Social Justice Activism in New York City. Athens: University of Georgia.

Rolf, W., Diehl, K., Zasada, I., and Wiggering, H. (2020). Integrating farmland into urban green infrastructure planning: an evidence synthesis for informed policymaking. Land Use Policy 99:104823. doi: 10.1016/j.landusepol.2020.104823

Saha, M., and Eckelman, M. J. (2017). Growing fresh fruits and vegetables in an urban landscape: a geospatial assessment of ground level and rooftop urban agriculture potential in Boston, USA. Landsc. Urban Plan. 165, 130-141. doi: 10.1016/j.landurbplan.2017.04.015

Shackleton, C. M., Hurley, P. T., Dahlberg, A. C., Emery, M. R., and Nagendra, H. (2017). Urban foraging: a ubiquitous human practice overlooked by urban planners, policy, and research. Sustainability 9:1884. doi: 10.3390/su9101884

Shackleton, C. M., Pasquini, M. W., and Drescher, A. W. (Eds.). (2009). African Indigenous Vegetables in Urban Agriculture. London: Earthscan. doi: $10.4324 / 9781849770019$

Shillington, L. J. (2013). Right to food, right to the city: household urban agriculture, and socionatural metabolism in Managua, Nicaragua. Geoforum 44, 103-111. doi: 10.1016/j.geoforum.2012.02.006

Siegner, A., Sowerwine, J., and Acey, C. (2018). Does urban agriculture improve food security? Examining the nexus of food access and distribution of urban produced foods in the United States: a systematic review. Sustainability 10:2988. doi: 10.3390/su10092988

Soulard, C.-T., Perrin, C., and Valette, E. (2017a). "Relations between agriculture and the city in Europe and the mediterranean," in Toward Sustainable Relations Between Agriculture and the City (Cham: Springer) p. 1-11. doi: 10.1007/978-3-319-71037-2_1

Soulard, C.-T., Perrin, C., and Valette, E. (eds.). (2017b). Toward Sustainable Relations between Agriculture and the City. Cham: Springer International Publishing. doi: 10.1007/978-3-319-71037-2

Soulard, C.-T., Valette, E., Perrin, C., Abrantes, P. C., Anthopoulou, T., et al. (2018). Peri-urban agro-ecosystems in the Mediterranean: diversity, dynamics, and drivers. Region. Environ. Change 18, 651-662. doi: 10.1007/s10113-017-1102-z
Surls, R., Feenstra, G., Golden, S., Galt, R., Hardesty, S., Napawan, C., et al. (2015). Gearing up to support urban farming in California: preliminary results of a needs assessment. Renewable Agric. Food Syst. 30, 33-42. doi: $10.1017 /$ S1742170514000052

Taylor, J. R., and Lovell, S. T. (2014). Urban home food gardens in the Global North: research traditions and future directions. Agric. Human Values 31, 285-305. doi: 10.1007/s10460-013-9475-1

Thebo, A. L., Drechsel, P., and Lambin, E. F. (2014). Global assessment of urban and peri-urban agriculture: irrigated and rainfed croplands. Environ. Res. Lett. 9:114002. doi: 10.1088/1748-9326/9/11/114002

Thomaier, S., Specht, K., Henckel, D., Dierich, A., Siebert, R., Freisinger, U., et al. (2015). Farming in and on urban buildings: present practice and specific novelties of Zero-Acreage Farming (Z Farming). Renewable Agric. Food Syst. 30, 43-54. doi: 10.1017/S1742170514000143

Tornaghi, C. (2014). Critical geography of urban agriculture. Prog. Hum. Geogr. 38, 551-567. doi: 10.1177/0309132513512542

Tornaghi, C., and Dehaene, M. (2019). The prefigurative power of urban political agroecology: rethinking the urbanisms of agroecological transitions for food system transformation. Agroecol. Sustain. Food Syst. 44, 594-610. doi: 10.1080/21683565.2019.1680593

Travaline, K., and Hunold, C. (2010). Urban agriculture and ecological citizenship in Philadelphia. Local Environ. 15, 581-590. doi,: 10.1080/13549839.2010.487529

UN Habitat (2020). World Cities Report 2020: The Value of Sustainable Urbanization. Available online at: https://unhabitat.org/sites/ default/files/2020/10/wcr_2020_report.pdf (accessed November 30, 2020).

Ward, J., Ward, P., Saint, C., and Mantzioris, E. (2014). The urban agriculture revolution. Water J. Austr. Water Assoc. 41:69.

Ward, J. D., Ward, P. J., Mantzioris, E., and Saint, C. (2014). Optimising diet decisions and urban agriculture using linear programming. Food Secur. 6, 701-718. doi: 10.1007/s12571-014-0374-0

Warner, B. P., Walsh-Dilley, M., Nelson-Nuñez, J., and Duvall, C. S. (2020). Rural transformation in Latin America's changing climate. J. Latin Am. Geogr. 19, 10-25. doi: 10.1353/lag.2020.0069

WinklerPrins, A. M. G. A. (Ed.). (2017). Global Urban Agriculture. Boca Raton, FL: CABI. doi: 10.1079/9781780647326.0000

Yacamán Ochoa, C., Ferrer Jiménez, D., and Mata Olmo, R. (2020a). Green infrastructure planning in metropolitan regions to improve the connectivity of agricultural landscapes and food security. Land 9:414. doi: 10.3390/land9110414

Yacamán Ochoa, C., Matarán Ruiz, A., Mata Olmo, R., Macías Figueroa, Á., and Torres Rodríguez, A. (2020b). Peri-urban organic agriculture and short food supply chains as drivers for strengthening city/region food systemstwo case studies in Andalucía, Spain. Land 9:177. doi: 10.3390/land90 60177

Zasada, I. (2011). Multifunctional peri-urban agriculture-a review of societal demands and the provision of goods and services by farming. Land Use Policy 28, 639-648. doi: 10.1016/j.landusepol.2011.01.008

Zimmerer, K. S., and Carney, J. C. (2019). "How do demographic change and spatial integration interact with agrobiodiversity?" in Agrobiodiversity: Integrating Knowledge for a Sustainable Future, eds K. S. Zimmerer, and S. de Haan (Cambridge: MIT Press), p. 163-182. doi: $10.7551 /$ mitpress/11989.001.0001

Zimmerer, K. S., De Haan, S., Jones, A. D., Creed-Kanashiro, H., Tello, M., Amaya, F. P., et al. (2020b). Indigenous smallholder struggles in Peru: nutrition security, agrobiodiversity, and food sovereignty amid transforming global systems and climate change. Journal of Latin American Geography 19, 74-111. doi: 10.1353/lag.2020.0072

Zimmerer, K. S., de Haan, S., Jones, A. D., Creed-Kanashiro, H., Tello, M., Carrasco, M., et al. (2019). The biodiversity of food and agriculture (agrobiodiversity) in the anthropocene: research advances and conceptual framework. Anthropocene 25, 1-16. doi: 10.1016/j.ancene.2019.100192

Zimmerer, K. S., Jiménez Olivencia, Y., Ruíz Ruíz, A., and Porcel Rodríguez, L. (2020a). Agri-food land transformations and immigrant farm workers in peri-urban areas of Spain and the Mediterranean. Land 9:472. doi: $10.3390 /$ land 9120472 
Zimmerer, K. S., Rojas Vaca, H. L., and Hosse Sahonero, M. T. (2021). Entanglements of agrobiodiversity-food amid cascading migration, coca conflicts, and water development (Bolivia, 1990-2013). Geoforum. doi: 10.1016/j.geoforum.2021.01.028

Conflict of Interest: The authors declare that the research was conducted in the absence of any commercial or financial relationships that could be construed as a potential conflict of interest.
Copyright (C) 2021 Zimmerer, Bell, Chirisa, Duvall, Egerer, Hung, Lerner, Shackleton, Ward and Yacamán Ochoa. This is an open-access article distributed under the terms of the Creative Commons Attribution License (CC BY). The use, distribution or reproduction in other forums is permitted, provided the original author(s) and the copyright owner(s) are credited and that the original publication in this journal is cited, in accordance with accepted academic practice. No use, distribution or reproduction is permitted which does not comply with these terms. 